\title{
EFFECTS OF THE METHANOL EXTRACT OF THE LEAVES OF MASTIC (SCHINUS TEREBINTHIFOLIUS RADDI) ON THE IN VITRO GROWTH OF CORYNEBACTERIUM PSEUDOTUBERCULOSIS
}

\author{
Cláudia Valle Cabral Dias dos Santos Veterinarian, Adjunct Professor of Bio- \\ chemistry, Health Sciences Center, Uni- \\ versidade Federal do Recôncavo da Bahia, \\ Brazil. \\ André Nascimento Santos Undergraduate medical student at the Sta- \\ te University of Feira de Santana, Bahia, \\ Brazil. \\ Luiz Erlon Rodrigues PhD, Adjunct Professor of Medical Bio- \\ chemistry, Bahiana School of Medicine \\ and Public Health, Salvador, Bahia, Brazil.
}

Corresponding author

Luiz Erlon Rodrigues

E-mail: erlon@svn.com.br

\begin{abstract}
Plants produce molecules such as terpenes, alkaloids and lectins that are active anticancer, antimicrobial and anti-inflammatory. Corynebacterium pseudotuberculosis is the etiological agent of caseous lymphadenitis in goats and sheep. The prevalence of infection is high in northeastern Brazil. The present study evaluated the effects of a methanol extract from the leaves of the mastic plant (Schinus terebinthifolius Raddi) on growth in vitro of virulent and attenuated strains of this bacillus. The extract was tested at concentrations of 2000, 1500, 1000, 500, 250, 100 and $10 \mathrm{ug} / \mathrm{dl}$ for 48 hours. The first four concentrations of growth inhibition, producing zones of decreasing diameters. No antibacterial effect was found with concentrations remaining. These results show that growth of bacteria is inhibited by an extract from Schinus Terebinthifolius Raddi in the concentrations mentioned above.
\end{abstract}

Keywords: Schinus terebinthifolius Raddi; Phytotherapy; Corynebacterium pseudotuberculosis. 


\section{INTRODUCTION}

Corynebacterium pseudotuberculosis is the etiological agent of caseous lymphadenitis in sheep and goats, ulcerative dermatitis in cattle and ulcerative lymphangitis in horses. It is an infectious and contagious disease characterized by abscesses in lymph nodes and visceral lesions. The microorganism was identified in countries with large populations of small ruminants, such as Australia, New Zealand, Argentina, South Africa, United States and European Union countries. ${ }^{(1)}$ In northeastern Brazil, there is a high prevalence of caseous lymphadenitis in goat breeding farms, resulting in considerable financial losses, especially for small farmers for whom raising goats is their main source of income. The lesions caused by caseous lymphadenitis may result in mastitis, which leads to a reduction in milk production. In addition, abscesses can damage the skin of the animal, resulting in sentence meat and, consequently, generate serious economic problems. ${ }^{(2,3)}$ The use of plant species to treat and cure diseases perpetuated throughout the history of civilization and persists today. Polyphenols represent an important class of substances that are widely present in the plant kingdom and part of the diet of animals and humans, being found in the form of wine, fruit juices, teas, coffee and numerous plant-derived. ${ }^{(4)}$ Among the polyphenols, flavonoids are a group of about 4,000 phenolic compounds, low molecular weight. Flavonoids are found in vascular plants and are associated with the color of fruits, flowers and leaves, as well as their defense mechanisms against ultraviolet radiation and infection by pathogens. ${ }^{(14)}$ A broad spectrum of biological activities have been attributed to flavonoid, including anticancer effect, antibacterial, antiviral, anti-inflammatory, antihypertensive, antiulcer and hypolipidemic. ${ }^{(5,6)}$ Queires et al. ${ }^{(7)}$ isolated some of the plant polyphenols mastic (Schinus terebinthifolius Raddi) and studied their antiproliferative effect on prostate cancer cells in human culture. Those researchers reported that phenols evaluated inhibited the proliferation of stimulated cells and apoptosis. According Queires \& Rodrigues, ${ }^{(8)}$ the aroeira is an excellent source of polyphenols, which when isolated in the form of extracts can be used in treating or controlling a variety of microorganisms and parasitic diseases in humans, animals, and plant. In view of these results, the present study evaluated the effects of different concentrations of a methanol extract from the leaves of the aroeira in vitro growth of Corynebacterium pseudotuberculosis.

\section{MATERIALS AND METHODS}

Methanolic extracts were obtained by selecting plant leaves by washing in water and the drying in an oven at $60^{\circ} \mathrm{C}$ until their weight became constant. Then, they were 
crushed and placed in a plastic bag under negative pressure and stored at $-20^{\circ} \mathrm{C}$ until further analysis. For each gram of ground sheet $10 \mathrm{ml}$ of methanol were added in a first hot extraction in a water bath held at $60^{\circ} \mathrm{C}$ under constant stirring for $10 \mathrm{~min}$ utes. After filtration on filter paper quality, the total volume was reduced to $25 \%$ of the initial volume on a rotary evaporator, heated to $70^{\circ} \mathrm{C}$ under negative pressure. The resulting methanol extract was vacuum filtered through filter-sterilized 5 micrometer pore size, which is stored in an opaque bottle and frozen at $-70^{\circ} \mathrm{C} .{ }^{(7)}$ Total phenol concentration was measured using the Folin according to the technique described by Queires \& Rodrigues. ${ }^{(8)}$ The dried methanol extract obtained from one milliliter of the concentrated solution was weighed and diluted with sterile distilled water to obtain the different concentrations used in the microbiological testing. Methanol diluted with distilled water to $50 \% \mathrm{v} / \mathrm{v}$ was used in control samples. For bacterial cultures, attenuated strain were used VD57 and T1 virulent strain. These strains were isolated from abscesses of goats with caseous lymphadenitis and were kept in the collection of the Microbiology Unit of the Institute of Health Sciences, Federal University of Bahia. The strains were identified as Corynebacterium pseudotuberculosis by API Coryne system (Biomerieux, France). The culture was performed in a glass flask containing broth, brain heart infusion (BHI) maintained in an oven at $37^{\circ} \mathrm{C}$ under aerobic bacteriological. The culture was reseeded every 48 hours until satisfactory growth was obtained. Drigalski loop was used to transfer and inoculating a volume of 500 microliters of broth to solid media of each plate. ${ }^{(9)}$ A total of 40 BHI agar plates containing solids were used, with strains and distributed extract. Filter paper disks with a diameter of $6 \mathrm{~mm}$ were placed in all plates. The discs performed in a volume of 10 microliters of aroeira extract with phenol concentration 2000, 1500, 1000, 500, 250100 and 10 ug / dl. The plates were incubated for 48 hours. The in vitro growth of bacteria was expressed in mean \pm standard deviation. Analysis of variance and Tukey test were performed and the Statistical Package for Social Sciences (SPSS) version 13.0 for Windows was used throughout the analysis. The differences between controls and the different concentrations of plant extracts were considered statistically significant when $\mathrm{p}$ values were $<0.05$.

\section{RESULTS AND DISCUSSION}

The methanolic extract was found to exert microbicidal activity in both strains at concentrations of 2000,1500, 1000 and $500 \mathrm{ug} / \mathrm{dL}$ after 48 hours of exposure. The concentrations of 250,100 and $10 \mathrm{ug} / \mathrm{dl}$ showed no antibacterial activity on either of the two strains tested. Figure 1 shows a plate in which the attenuated strain T1 was exposed to methanol extract, while figure 2 shows the same growth inhibi- 
tion test using VD57 virulent strain. Table 1 summarizes the results were expressed as the mean \pm standard deviation of the diameters of zones of inhibition for both bacterial strains.

Figure 1 - The effect of the methanolic extract from aroeira plant (Schinus terebinthifolius Raddi) on the growth of Corynebacterium pseudotuberculosis. Attenuated strain, T1

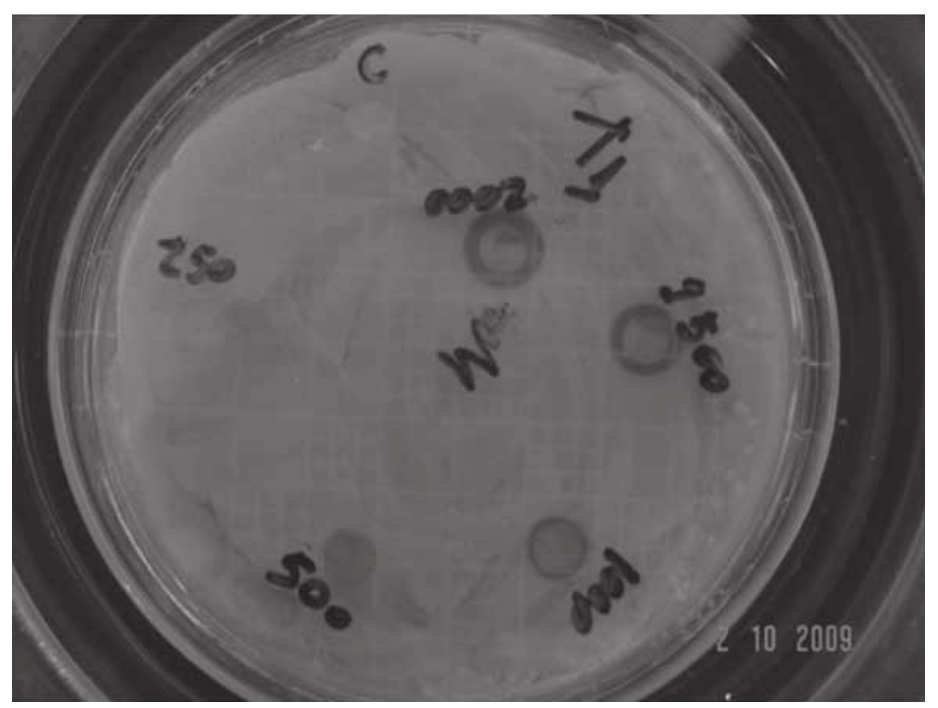

Figure 2 - The effect of the methanolic extract from aroeira plant (Schinus terebinthifolius Raddi) on the growth of Corynebacterium pseudotuberculosis. Virulent strain, VD57

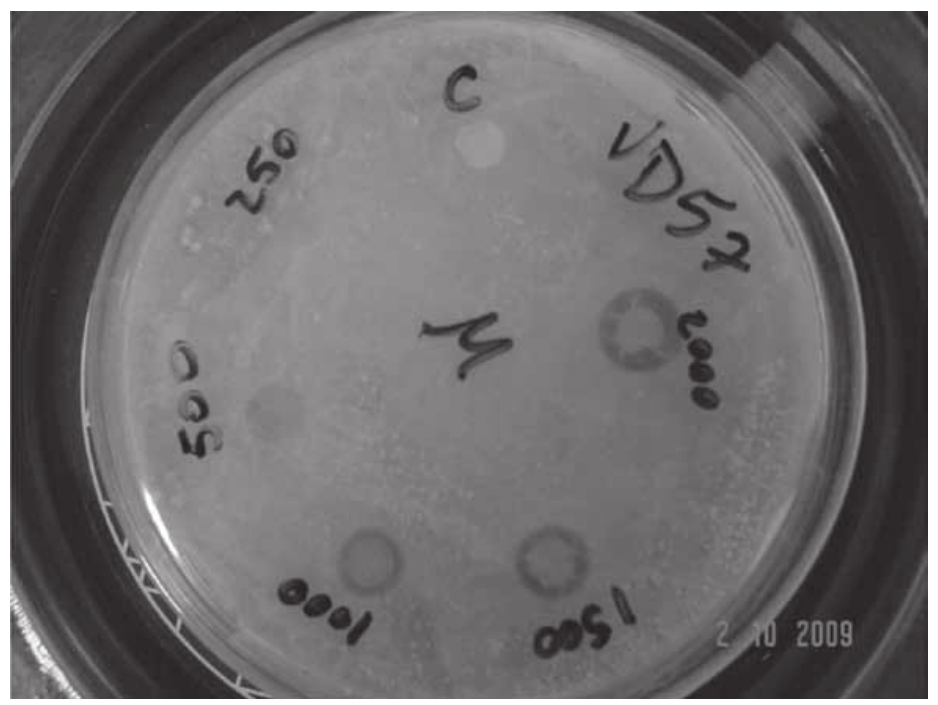


Table 1 - Inhibition halo diameters (means \pm standard deviations) in the growth tests following exposure of the two strains of Corynebacterium pseudotuberculosis for 48 hours to the methanolic extract of the aroeira plant (Schinus terebinthifolius Raddi)

\begin{tabular}{c|c|c|c|c}
\hline \multirow{2}{*}{$\begin{array}{c}\text { Concentrations of } \\
\text { methanolic extract }\end{array}$} & \multicolumn{2}{|c}{ T1 Strain } & \multicolumn{2}{c}{ VD57 Strain } \\
\cline { 2 - 5 } & Average & $\begin{array}{c}\text { Standard } \\
\text { Deviation }\end{array}$ & Average & $\begin{array}{c}\text { Standard } \\
\text { Deviation }\end{array}$ \\
\hline \multirow{2}{*}{$\begin{array}{c}\text { Negative control } \\
(\text { methanol } 50 \%)\end{array}$} & --- & -- & -- & -- \\
\hline $2.000 \mu \mathrm{g} / \mathrm{mL}$ & $10.8 \mathrm{~mm}$ & $\pm 0.45 \mathrm{~mm}$ & $10.75 \mathrm{~mm}$ & $\pm 0.5 \mathrm{~mm}$ \\
\hline $1.500 \mu \mathrm{g} / \mathrm{mL}$ & $10.2 \mathrm{~mm}$ & $\pm 0.45 \mathrm{~mm}$ & $9.5 \mathrm{~mm}$ & $\pm 0.58 \mathrm{~mm}$ \\
\hline $1.000 \mu \mathrm{g} / \mathrm{mL}$ & $8.4 \mathrm{~mm}$ & $\pm 0.55 \mathrm{~mm}$ & $7.75 \mathrm{~mm}$ & $\pm 0.5 \mathrm{~mm}$ \\
\hline $500 \mu \mathrm{g} / \mathrm{mL}$ & $7.0 \mathrm{~mm}$ & $\pm 0.1 \mathrm{~mm}$ & $7.0 \mathrm{~mm}$ & $\pm 0.1 \mathrm{~mm}$ \\
\hline
\end{tabular}

Puupponen-Pimiä et al. ${ }^{(10)}$ tested the antimicrobial properties of phenolic compounds isolated from fruits and reported the growth inhibition of Gram-negative bacteria, but not gram-positive bacteria and it is concluded that the sensitivity of bacteria to various kinds of phenolic compounds differs. Degaspari, Waszczynskyj \& Prado $^{(11)}$ analyzed the antimicrobial activity of aqueous and alcoholic extracts obtained from fruits of mastic. The alcoholic fraction had an inhibitory effect on the growth of Staphylococcus aureus and Bacillus cereus, and was found to contain significant amounts of flavone apigenin and ellagic acid. The aqueous fraction had no antimicrobial effect and found to contain naringin flavone. Soares et al. ${ }^{(12)}$ reported that the ability of alcoholic extract of mastic (Schinus Terebinthifolius Raddi) to inhibit the growth of several species of bacteria of the genus Streptococcus was significant, and described in even greater capacity of the extract to inhibit Staphylococcus aureus. In 2008, Abreu et al. ${ }^{(13)}$ assessed the sensitivity of 31 samples of Corynebacterium pseudotuberculosis isolated from goats and sheep in Pernambuco, Brazil to many antibiotics in vitro. It was found that $87.1 \%$ of the isolates were resistant to novobiocin, $80.6 \%$ neomycin, gentamicin, $41.9 \%$ to $19.3 \%$ lincomycin, $16 \%$ to ampicillin, penicillin and orbifloxacin, and lower percentage, the trimethoprim-sulfa, cefazolin, norfloxacin, amoxicillin, ciprofloxacin, chloramphenicol and tetracycline. With the exception of a strain, all others showed some degree of multidrug resistance to various chemotherapeutic agents, it became clear that the sensitivity of bacteria varies. Costa et al. (2010) concluded that the ethanol extract of Schinus terebinthifolius (aroeira-da-praia) and Astronium urundeuva (aroeira-do-sertão) were found to have an effect against Enterococcus faecalis. 


\section{CONCLUSION}

The formation of halos of growth inhibition for these strains of Corynebacterium pseudotuberculosis shows the microbicidal effect of the methanol extract of Schinus terebinthifolius Raddi. This effect can be at least partially due to total phenolic content in $\mathrm{g} / \mathrm{dl}$ concentrations 2000, 1500, 1000 and 500 after 48 hours of exposure. These results suggest that clinical trials should be performed to evaluate the in vivo effect of the addition of aroeira leaves for feeding animals infected with Corynebacterium pseudotuberculosis as an adjunct to conventional treatment of this infection.

\section{REFERENCES}

1. Fontaine MC, Baird GJ. Caseous lymphadenitis. Small Rumin Res. 2008;76:42-48.

2. Moura-Costa LF. Corynebacterium pseudotuberculosis, o agente etiológico da linfadenite caseosa em caprinos. Rev ciênc méd biol. 2002;1(1):105-115.

3. Dorella AF, Pacheco LGC, Oliveira SC, Miyoshi A, Azevedo V. Corynebacterium pseudotuberculosis: microbiology, biochemical properties, pathogenesis and molecular studies of virulence. Vet Res. 2006;37:201-218.

4. Carlo G, Macolo N, Izzo AA, Capasso F. Flavonoids old and new aspects of a class of natural therapeutics drugs. Life Sciences. 1999;65(4):337-353.

5. Aherne SA, O'Brien NM. The flavonoids, myricetin, quercetin and rutin, protect against cholestan$3 \beta, 5 a, 6 \beta$-triol - induced toxicity in chinese hamster ovary cells in vitro. Nutr Res. 1999;19(5):749760 .

6. Havsteen $\mathrm{BH}$. The biochemistry and medical significance of the flavonoids. Pharmacology Therapeutics. 2002;96(2-3): 67-202.

7. Queires LC, Fauvel-Lafetve F, Terry S, Taille A, Chopin DK, Vacherot F et al. Polyphenols purified from Brazilian aroeira plant (Schinus terebinthifolius, Raddi) induce apoptotic and autophagic cells death of DU145 cells. Anticancer Res. 2006; 26:379-388.

8. Queires LCS, Rodrigues LEA. Quantificação das substâncias fenólicas totais em órgãos da aroeira Schinus terebinthifolius (RADDI). Braz arch boil technol. 1998;41(2):247-253.

9. Moura-Costa LF, Paule BJA, Azevedo V, Freire SM, Nascimento L, Schaer R et al. Meio sintético quimicamente definido para o cultivo de Corynebacterium pseudotuberculosis. Rev bras saúde prod anim. 2002;3(1):1-9.

10. Puupponen-Pimia R, Nohynek L, Meier C, Kahkonen M, Heinonen M, Hopia A et al. Antimicrobial properties of phenolic compounds from berries. J Appl Microbiol. 2001;90:494-507.

11. Degáspari CH, Waszczynskyj N, Prado MRM. Antimicrobial activity of Schinus terebenthifolius Raddi. Ciênc Agrotec. Lavras. 2005;29(3):617-622.

12. Soares DGS, Oliveira CB, Leal C, Drumond MRS, Padilha WWN. Susceptibilidade in vitro de bactérias bucais à tinturas fitoterápicas. Rev odonto ciênc. 2006;21(53):232-237.

13. Abreu SRO, Mota RA, Pinheiro Júnior JW, Rosinha GMS, Castro RS. Perfil de sensibilidade antimicrobiana in vitro de isolados de Corynebacterium pseudotuberculosis de caprinos e ovinos com linfadenite caseosa no sertão de Pernambuco, Brasil. Vet Zootec. 2008;15(3):502-509. 
14. Rodrigues LEA. Vitaminas - Verdades \& Mitos. Belo Horizonte: Ed. O Lutador; 2004. p. 227-239.

15. Costa EMMB, Barbosa ASB, Arruda TA, Oliveira PT, Dametto FR, Carvalho RA et al. Estudo in vitro da ação antimicrobiana de extratos de plantas contra Enterococcus faecalis. J. bras. patol. med. lab. 2010;46(3):175-180. 